\title{
Azolla Cultivation to Produce Sustainable Feed Ingredient: Chemical Composition and its Impact on Performance of Broiler Chickens
}

\author{
Rohan Kumar Sharma ${ }^{1}$, A.K. Pathak ${ }^{1 *}$, R.K. Sharma ${ }^{1}$ and Neelesh Sharma ${ }^{2}$ \\ ${ }^{1}$ Division of Animal Nutrition, Faculty of Veterinary Sciences $\mathcal{E}$ AH, Sher-e-Kashmir University of Agricultural Sciences and \\ Technology of Jammu, R.S. Pura, J EK, INDIA \\ ${ }^{2}$ Division of Veterinary Medicine, Faculty of Veterinary Sciences $\mathcal{E}$ AH, Sher-e-Kashmir University of Agricultural Sciences and \\ Technology of Jammu, R.S. Pura, J \& K, INDIA \\ "Corresponding author: AK Pathak; E-mail: dranand_pathak@yahoo.com
}

Received: 10 Oct., 2020

Revised: 02 Nov., 2020

Accepted: 08 Nov., 2020

\begin{abstract}
Present study was conducted in two phases. In phase 1, fresh azolla was cultivated, harvested and analysed for nutrient composition, condensed tannins (CT) and obtained dried azolla meal (DAM) for incorporation in broiler ration. In phase 2, feeding trial was conducted to investigate the effect of DAM supplementation as alternative feed ingredient in broiler ration. Day-old broiler chicks (180) were purchased, weighed individually and allocated into six treatments $\left(\mathrm{T}_{0}, \mathrm{~T}_{1}, \mathrm{~T}_{2}, \mathrm{~T}_{3}, \mathrm{~T}_{4}\right.$ and $\left.\mathrm{T}_{5}\right)$ groups supplemented with DAM @ 0.0, 1.5, 2.5, 3.5, 4.5 and 5.5 percent, respectively. Each group has 3 replicates and 10 chicks per deep litter pen. Experimental birds were fed their respective diets for 35 days. The DAM contains 86.94, 22.98, 3.13, 13.64, $13.06,40.37,1.23,0.79$ and 0.09 percent of organic matter $(\mathrm{OM})$, crude protein $(\mathrm{CP})$, ether extract (EE), crude fibre $(\mathrm{CF})$, total ash, nitrogen free extract (NFE), calcium (Ca), phosphorus (P) and condensed tannins (CT), respectively. The weight gain and feed conversion ratio (FCR) at weekly intervals did not differ significantly $(\mathrm{P}>0.05)$ irrespective of groups except feed intake. It was concluded that DAM incorporation up to $5.5 \%$ of diet is a good source of nutrients and as an alternative sustainable feed ingredient for broilers without affecting performance.
\end{abstract}

\section{HIGHLIGHTS}

(0 Azolla can be used as alternative feed resources for poultry.

0 Feeding of dried azolla meal as unconventional feed resource does not hamper any growth performance of broiler.

Keywords: Azolla, Broilers, Chemical composition, Performance

Broiler chicken production has become a rapidly developing enterprise to the rural as well as commercial poultry farmers. In Jammu and Kashmir, as a part of food habit, per capita consumption of meat and poultry is higher than in other states of India, but it is deficit in meat, poultry and eggs production thus making state to heavily rely on imports from nearby states (Pathak et al., 2019; Zargar et al., 2020). Due to mismatch in demand and supply of the animal protein sources, the imports of these animal protein sources are continuously increasing. The state spends annually hundreds of crores of rupees on the import of mutton and poultry from nearby states (ESJK, 2014).
The greatest challenges faced by the poultry farmers in Jammu and Kashmir, is the shortage of good quality of feeds at cheaper rates, mainly due to increased human and livestock population, urbanization and rapid shrinkage of agriculture cultivated land for crop production. Further the availability of traditional sources of poultry feeds like cereal grains and oil seed cakes are also declining due to export policy and increased cultivation of other cash crops.

How to cite this article: Sharma, R.K., Pathak, A.K., Sharma, R.K. and Sharma, N. (2020). Azolla cultivation to produce sustainable feed ingredient: chemical composition and its impact on performance of broiler chickens. J. Anim. Res., 10(6): 1067-1075.

Source of Support: None; Conflict of Interest: None 
Such varied factors have contributed in an inter-linked way to aggravate the poultry feed crisis. Hence to make broiler production a profitable enterprise, there is a great need to use alternative unconventional feedstuffs having good nutrient profile replacing the traditional sources. This can leads to search for cheaper and easily available alternative feed resources.

Aquatic plants have long been used in many developing countries as feed resource for poultry. Azolla grows naturally in stagnant water of drains, canals, ponds, rivers and in marshy lands. It has long been recognized as a feed for wildfowl in the USA and for domesticated ducks in China. Poultry, particularly ducks and chickens, can be raised on a diet containing fresh azolla. It is an unconventional potential feed ingredient for broilers. It can be used as alternative plant protein source, mineral and pro-vitamins source for poultry nutrition (Rana et al., 2017). It can increase flexibility of diet and makes possibility for cheaper broiler production (Lakshmanan et al., 2017; Sinha et al., 2018). On dry weight basis, it contains $25-35 \%$ protein, $13.8 \%$ crude fibre, $4.55 \%$ ether extract and $10.06 \%$ ash, $10-15 \%$ mineral and $7-10 \%$, a combination of amino acids, bio-active compounds and biopolymers (Kathirvelan et al., 2015). Among the feed proteins plant originates are less costly than animal protein.

In order to meet the increased nutritional demands of poultry, every poultry farmer must adopt a new technology to produce a nutritionally rich alternative feed in a limited area, in particular those who have too little land for alternative feeds production. There has been no study on performance and nutrient utilization of broiler chickens on dried azolla meal (DAM) as alternative feed ingredient in Jammu and Kashmir. Keeping this in view, it is proposed to cultivate, analyse its chemical composition and to see the impact of DAM on broiler chicken performance as alternative sustainable feed ingredient.

\section{MATERIALS AND METHODS}

Present study was carried out in two phases. In phase-I, fresh azolla was cultivated, processed for preparation of dried azolla meal (DAM) and then analysed for its chemical composition and presence of phytochemical especially condensed tannins (CT) in the Animal Nutrition Laboratory. However, in phase-II, in-vivo feeding trial was carried out the poultry shed, Division of ILFC, FVSc
\& AH, SKUAST-J, R.S. Pura, Jammu to determine the growth performance, nutrient intake, utilization and their retention in broiler chickens.

\section{Azolla Cultivation}

For experimental purpose, the location and site for cultivation of Azolla was identified under the shed of trees and near the water source for filling of artificial pits to maintain sufficient water level in the azolla cultivated pits. The fresh azolla was cultivated in three artificial ponds/ fits of $14 \times 14 \times 1$ feet (as length $\times$ width $\times$ height) dimension which were prepared in front of Division of Animal Nutrition and these pits were covered with polythene sheet to avoid water leakage. The pits were filled with water from the well and the fertile soil (8-10 $\mathrm{kg} / \mathrm{pit})$ spread uniformly. The slurry of normal fresh cow dung $(1.5 \mathrm{~kg} /$ week/ pit) and triple super phosphate $(45 \%$ P) (20-30 g/ week/ pit) were mixed in water of all three pits. This practice was followed at weekly interval in each pit for cultivation of Azolla pinnata. More water is poured on to raise the water level to about $10 \mathrm{~cm}$. For cultivation, azolla culture was obtained from KVK, R. S. Pura. About $0.5 \mathrm{~kg}$ of fresh and pure culture of $A$. pinnata was placed in three pits ready for cultivation. That's why the $A$. pinnata multiplied rapidly and filled the pit within a week (Fig. 1).

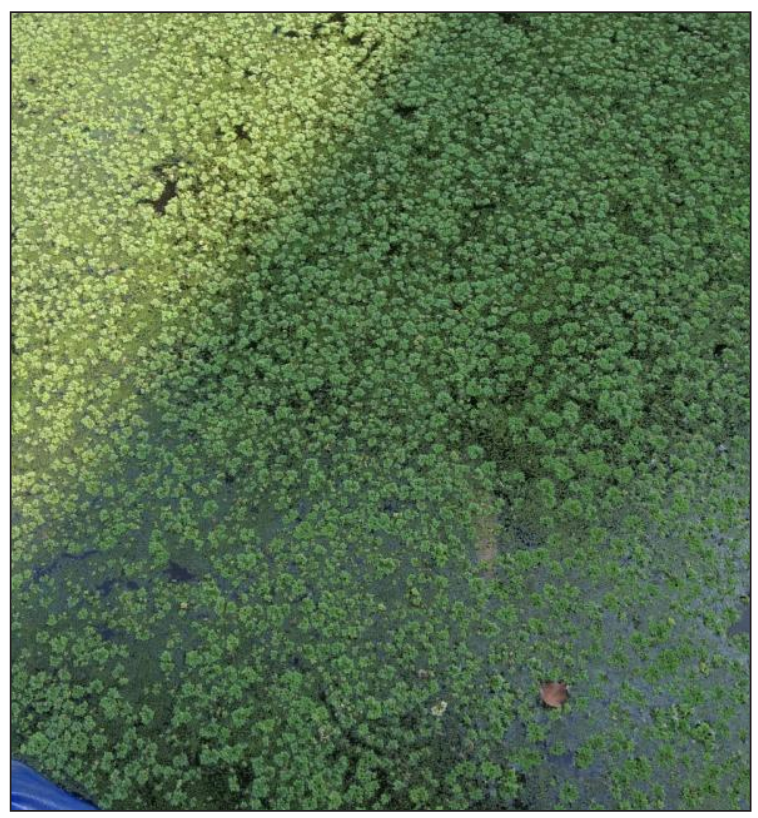

Fig. 1: Showing Azolla cultivation in Pits covered with polythene sheet 


\section{Azolla harvesting}

Fresh azolla was harvested with a scoop net from each pit at weekly interval, and then thoroughly washed with fresh and clean tap water to remove dirt and debris. After cleaning, the representative samples were brought to the laboratory for determination of moisture/ dry matter content. While, remaining harvested azolla plants were spread on plastic sheet for drying in sun light as well as in shed (Fig. 2, 3). Cultivation of $A$. pinnata continued over the period of 3 months for obtaining sufficient amount of DAM for feeding of experimental broiler chickens according to approved study plan.

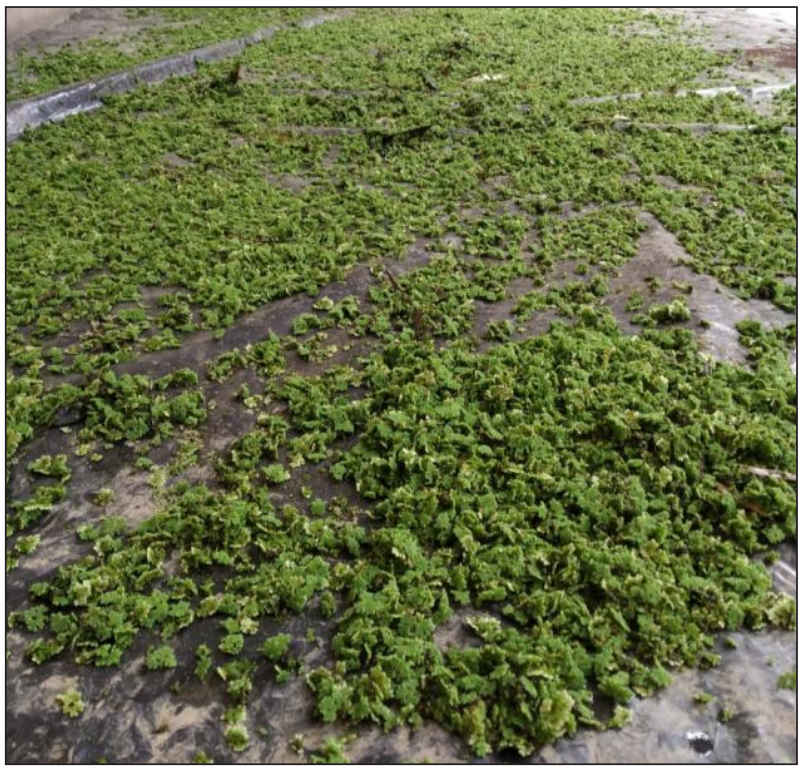

Fig. 2: Showing sun drying of Azolla for preparation of dried Azolla meal

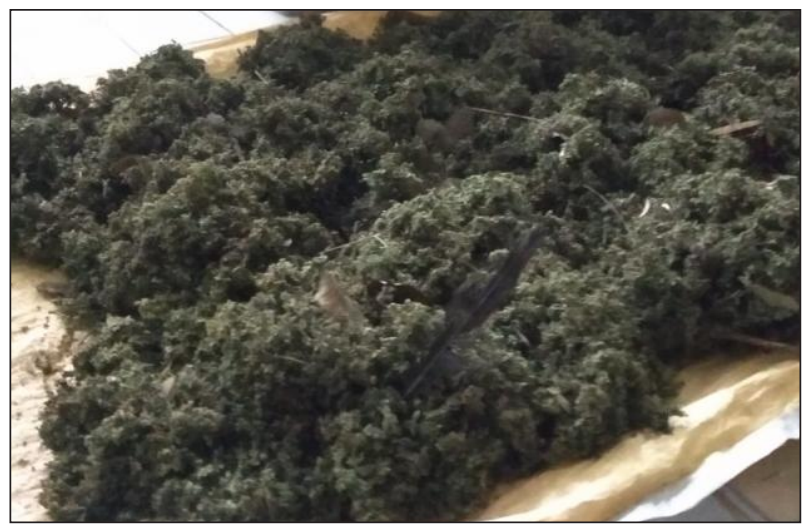

Fig. 3: Showing sun dried Azolla ready for preparation of DAM

\section{Determination of chemical composition of Azolla pinnata}

Properly washed, neat, clean and weighed amount of fresh azolla samples were put in previously weighed aluminium trays and then these trays were kept in hot air oven at $65^{\circ} \mathrm{C}$ for 48 hours to determine the moisture/ dry matter content. The oven dried samples were processed for further nutritional analysis. Dried azolla meal (DAM) and experimental broiler feed, residues and faecal samples were ground to $1 \mathrm{~mm}$ size in electric grinder and then chemically analyzed in triplicate for their proximate composition as per AOAC (2007). Fibre fractions viz. neutral detergent fibre (NDF) and acid detergent fibre (ADF) of DAM were determined according to Van Soest et al. (1991). Calcium (Ca) and phosphorus (P) contents were analysed as per the methods described by Talpatra et al. (1940) and AOAC (2000), respectively. The extraction and quantification of $\mathrm{CT}$ in fat and pigment free DAM sample was performed as per the method described by Makkar (2000) and Porter et al. (1986), respectively.

\section{Experimental design, feeds, management and feeding schedule}

In phase-2, in-vivo experiment was accomplished in 180 day-old broiler chicks (Cobb-K strain) for a period of 5 weeks in a completely randomized block design (CRD). After arriving of chicks, they were weighed individually (average body weight $44 \pm 0.23 \mathrm{~g}$ ) and then randomly distributed into 6 treatment groups each having 3 replicates with 10 chicks per replicate. All experimental chicks were maintained under electric brooder for first 10 days and then shifted in the separate deep litter pens. Properly dried rice husk was used as a litter material. All management conditions viz, temperature, humidity, feeding, watering and lightening arrangement were equally maintained in the poultry shed. The DAM was supplemented at the rate of $0,1.5,2.5,3.5,4.5$ and 5.5 percent, respectively in $\mathrm{T}_{0}, \mathrm{~T}_{1}, \mathrm{~T}_{2}, \mathrm{~T}_{3}, \mathrm{~T}_{4}$ and $\mathrm{T}_{5}$ treatment groups. Experimental broiler chick diets were iso-caloric and iso-nitrogenous. These experimental diets were formulated according to ICAR (2013) specifications. Experimental birds were fed on their respective diets ad libitum from 0 to $5^{\text {th }}$ weeks as per experimental feeding schedule. The experimental feeding schedule was designed as-

$$
\mathrm{T}_{1} \text { : Control (basal feed) }+0 \% \text { DAM }
$$




$$
\begin{array}{ll}
\square & \mathrm{T}_{2}: \text { Control + } 1.5 \% \text { DAM } \\
\square & \mathrm{T}_{3}: \text { Control + } 2.5 \% \text { DAM } \\
\square & \mathrm{T}_{4}: \text { Control + } 3.5 \% \text { DAM } \\
\square & \mathrm{T}_{5}: \text { Control + } 4.5 \% \text { DAM } \\
\square & \mathrm{T}_{6}: \text { Control + } 5.5 \% \text { DAM }
\end{array}
$$

\section{Performance parameters}

Feed offered and feed refusal data were recorded daily to quantify daily feed consumed. However, body weight, weight gain, feed intake and feed conversion ratio (FCR) data were calculated at weekly intervals for 35 days on bird basis. The weight gain, feed intake and FCR data were calculated at weekly intervals on bird basis. The following calculations were conducted as given below:

Weight gain $(\mathrm{g})=$ Mean final weight $(\mathrm{g})$ - Mean initial weight $(\mathrm{g})$

$\mathrm{FCR}=$ Feed intake $(\mathrm{g}) /$ Weight gain $(\mathrm{g})$

\section{Statistical analysis}

Statistical analysis of the data generated was performed using SPSS software in a personal computer. Generalized linear model (GLM) multivariate analysis was performed for analysis of periodic body weight, weight gain, feed intake and FCR. However, data of nutrient intake, digestibility and their retention were performed using one way analysis of variance (ANOVA) as per the procedures of Snedecor and Cochran (2004). Means differing significantly $(\mathrm{P}<0.05)$ with each other were ranked as per Duncan's multiple range test (Duncan, 1955).

\section{RESULTS AND DISCUSSION}

\section{Proximate Composition of dried azolla meal (DAM)}

The proximate composition, $\mathrm{Ca}$ and $\mathrm{P}$ contents and fibre fractions (NDF and ADF) of DAM are presented in the table 1. The DM content of DAM was 92.16 percent. The DAM contained 86.94 percent OM, 22.98 percent CP, 3.11 percent EE, 13.64 percent $\mathrm{CF}, 13.06$ percent total ash (TA), 40.37 percent NFE, 1.23 percent calcium and 0.79 percent phosphorus.
The CP content of DAM in the present study was estimated as $22.98 \%$ which is consistent with the results of Balaji et al. (2009), Cherryl et al. (2013), Roy et al. (2016) and Shoukat Ara et al. (2015), who reported 23-25\% CP content. However, the present result was contradicted with Basak et al. (2002), Parthasarathy et al. (2002), Indira et al. (2009), Shamna et al. (2013) and Indira and Ravi (2014) who stated 25 to $28 \% \mathrm{CP}$, which were higher than the current finding. The value of EE $(3.11 \%)$ of DAM obtained in the present study is in harmony with the values reported by previous workers (Basak et al., 2002 and Balaji et al., 2009, Shoukat Ara et al., 2015). Whereas, lower EE values ranging from 1.60 to $2.93 \%$ were reported in previous studies (Parthasarathy et al., 2002; Alalade and Iyayi, 2006 and Shamna et al., 2013), while, the study of Indira et al. (2009) reported higher EE value in azolla compared to EE content in the present study. The CF content (13.64\%) of DAM obtained in the present study is comparable with the findings reported by previous workers (Khatun, 1996 and Alalade and Iyayi, 2006). However, Parthasarathy et al. (2002), Indira et al. (2009), Balaji et al. (2009) and Shamna et al. (2013) studies reported higher CF contents than that of the results obtained in the present study.

The Ca content $(1.23 \%)$ of DAM in the present study is in line with the value reported by Ali and Leeson (1995). However, Balaji et al. (2009) and Shamna et al. (2013) reported higher $\mathrm{Ca}$ values than that of the present results, while Parthasarathy et al. (2002 and Alalade and Iyayi (2006) reported lower Ca content. The P content of DAM $(0.79 \%)$ observed in the present study is in agreement with the value $(0.72 \%)$ reported by Parthasarathy et al. (2002). However, $\mathrm{P}$ content obtained in the present study is contradictory with the results of Alalade and Iyayi (2006) who reported higher $\mathrm{P}$ content.

The NDF and ADF values were 40.81 and 27.01 percent, respectively, in DAM on DM basis. However, the CT content of DAM was 0.085 percent. The NDF and ADF values of DAM were 40.81 and 27.01 percent on DM basis in the present study. The NDF and ADF values in the present study were similar to the findings of Parthasarathy et al. (2001) and Alalade and Iyayi (2006), whereas, present results are contradictory with the findings of Letermea et al. (2009) who reported higher NDF and ADF values for Azolla. Moreover, the condensed tannins (CT) content of DAM was 0.085 percent in the present study. 
Table 1: Chemical composition of dried azolla meal (DAM) and other feed ingredients

\begin{tabular}{lllll}
\hline \multirow{2}{*}{ Attributes } & \multicolumn{3}{c}{ Feed ingredients } \\
\cline { 2 - 5 } & DAM & Maize & Soybean meal & Rice bran \\
\hline Proximate principles & & & 92.54 & 91.83 \\
\hline Dry matter & 92.16 & 92.06 & 89.52 & 89.78 \\
Organic matter & 86.94 & 90.33 & 44.97 & 12.54 \\
Crude protein & 22.98 & 9.03 & 1.03 & 16.11 \\
Ether extract & 3.11 & 4.27 & 6.76 & 12.08 \\
Crude fibre & 13.64 & 4.49 & 10.48 & 10.22 \\
Total ash & 13.06 & 9.67 & 36.76 & 0.17 \\
Nitrogen free extract & 40.37 & 72.54 & & 1.34 \\
\hline Mineral contents & & & 0.98 & - \\
\hline Calcium & 1.23 & 0.02 & 0.67 & - \\
Phosphorus & 0.79 & 0.25 & - & - \\
\hline Fibre fractions & & & & \\
\hline Neutral detergent fibre & 40.81 & - & - & \\
Acid detergent fibre & 27.01 & - & & \\
\hline Poly-phenolic compounds & & - & & \\
\hline Condensed tannins (CT) & 0.085 & & & \\
\hline
\end{tabular}

The wide variations were exist in the chemical composition of dried azolla meal (DAM), which might be due to differences in the azolla strains, methods of cultivation and harvesting, methods of collection and processing, environmental conditions such as temperature, humidity, wind velocity and light intensity as well as nutrient profiling of soil, water and cow dung slurry which consequently affect azolla plants' growth morphology and nutrient composition. Furthermore, contamination with dirt, debris, fallen tree leaves and other epiphytic algae could also be important factors which affect the nutrient composition of dried azolla meal.

\section{Proximate composition of feed ingredients}

The proximate composition viz. DM, OM, CP, EE, CF, TA and NFE contents of other feed ingredients such as maize grain, soybean meal and rice bran were 92.06, 92.54, 91.83 ; 90.33, 89.52, 89.78; 9.03, 44.97, 12.54; 4.27, 1.03, $16.11,4.49,6.76,12.08 ; 9.67,10.48,10.22$ and 72.54 , $36.76,49.05$ percent, respectively in the present study. The calcium and phosphorus contents of maize, soybean meal and rice bran were 0.02 and $0.25 ; 0.98$ and 0.67 and 0.17 and 1.34 percent, respectively. The proximate composition, $\mathrm{Ca}$ and $\mathrm{P}$ contents of maize, soybean meal and rice bran in the present study were comparable the results reported by previous workers (Daing, 2015; Khan et al., 2017; 2019; Pathak et al., 2015; 2017 and Singh et al., 2015).

\section{Ingredient composition of experimental broiler diets}

Six experimental diets $\left(\mathrm{T}_{0}, \mathrm{~T}_{1}, \mathrm{~T}_{2}, \mathrm{~T}_{3}, \mathrm{~T}_{4}\right.$ and $\left.\mathrm{T}_{5}\right)$ for each phase i.e. broiler pre-starter, starter and finisher were formulated from locally available feed ingredients. The experimental diets of present study were prepared by using common feed ingredients such as crushed maize, rice bran, soybean meal, soybean oil, L-Lysine-Hcl, DLmethionine, di-calcium phosphate (DCP), lime stone powder (LSP), common salt and mineral vitamin premix by incorporating graded levels of DAM at $0,1.5,2.5$, 3.5, 4.5 and 5.5 percent in $\mathrm{T}_{0}, \mathrm{~T}_{1}, \mathrm{~T}_{2}, \mathrm{~T}_{3}, \mathrm{~T}_{4}$ and $\mathrm{T}_{5}$ diets, respectively. With and without DAM incorporated diets were prepared iso-caloric and iso-nitrogenous by minor adjustment with maize, soybean meal (SBM), rice bran (RB) and soybean oil (SBO), while the proportions of other feed ingredients viz. L-Lysine-Hcl, DL-methionine, DCP, LSP, common salt and premix were remained same in all experimental diets of each phase. The mineral vitamin premix was mixed at the rate of $375 \mathrm{~g}$ per $100 \mathrm{~kg}$ in all experimental diets of each phase. The proportions of the mineral vitamin premix in the diets of the present 
study are in harmony with the previous studies (Daing et al., 2020, Zargar et al., 2020).

\section{Nutrient composition of experimental broiler diets}

The metabolisable energy (ME; $\mathrm{kcal} / \mathrm{kg}$ ) and $\mathrm{CP}(\%)$ values were ranged from 2994 to 3003, 3048 to 3051 and 3097 to 3104 and 21.99 to $22.03,21.48$ to 21.54 and 19.49 to 19.53 , respectively in pre-starter, starter and finisher diets. Whereas, other parameters of experimental diet ( $T_{0}$ to $\left.T_{5}\right)$ in pre-starter, starter and finisher phases were ranged from OM (90.37-91.15; 89.57-90.29; 89.17-89.74), EE (4.424.77 ; 5.24-5.66; 5.96-6.09), CF (3.38-4.18; 3.87-4.67; 4.11- 4.55), NFE (59.51-60.97; 58.06-59.67; 59.16-60.03) and TA $(8.85-9.87 ; 9.71-10.43 ; 10.26-10.83)$, respectively. Furthermore, $\mathrm{Ca}$ and $\mathrm{P}$ contents in pre-starter, starter and finisher diets $\left(\mathrm{T}_{0}\right.$ to $\left.\mathrm{T}_{5}\right)$ were ranged from 0.89 to 0.94 , 0.86 to $0.98 \& 0.0 .88$ to 0.94 and 0.73 to $0.74,0.70$ to $0.76 \& 0.74$ to 0.78 percent, respectively. Present findings are comparable with the results reported by Daing et al. (2020) and Zargar et al. (2020).

All experimental diets of each phase of broiler chickens were formulated and adjusted to fulfil the micronutrients need as per the birds' nutrient requirements (ICAR, 2013) and avoid any deficit or excess of each and every nutrient during ration formulation. The purpose of providing the same level of other nutrients in all experimental diets of broiler chickens so that we can determine/ analyze the impact of DAM incorporation in broiler rations on growth performance.

\section{Performance of broiler chickens}

The impact of dietary incorporation of DAM on weekly live weight gain, feed intake and FCR of experimental broiler chicken is presented in the table 2. Mean weight gain and FCR of experimental broiler chickens at weekly intervals did not differ significantly $(\mathrm{P}>0.05)$ irrespective

Table 2: Effect of dried azolla meal incorporation on weekly weight gain, feed intake and feed conversion ratio in broiler chickens

\begin{tabular}{|c|c|c|c|c|c|c|}
\hline \multirow{2}{*}{ Groups } & \multicolumn{5}{|c|}{ Periods (week) } & \multirow{2}{*}{ GM $\pm \mathbf{P S E}$} \\
\hline & $\mathbf{1}^{\text {st }}$ & $2^{\text {nd }}$ & $3^{\text {rd }}$ & $4^{\text {th }}$ & $5^{\text {th }}$ & \\
\hline \multicolumn{7}{|c|}{ Weight gain (g) } \\
\hline$\overline{\mathrm{T}_{0}}$ & 83.13 & 163.26 & 197.33 & 358.07 & 483.50 & $257.06 \pm 12.26$ \\
\hline $\mathrm{T}_{1}$ & 85.50 & 170.68 & 199.09 & 355.95 & 490.87 & $260.42 \pm 12.25$ \\
\hline $\mathrm{T}_{2}$ & 83.88 & 171.98 & 190.13 & 364.97 & 485.57 & $259.30 \pm 12.21$ \\
\hline $\mathrm{T}_{3}$ & 83.38 & 174.02 & 185.10 & 375.03 & 481.10 & $259.73 \pm 12.42$ \\
\hline $\mathrm{T}_{4}$ & 82.77 & 173.46 & 188.07 & 376.49 & 487.92 & $261.74 \pm 12.55$ \\
\hline $\mathrm{T}_{5}$ & 62.36 & 192.31 & 189.43 & 376.23 & 493.23 & $262.71 \pm 12.76$ \\
\hline $\mathbf{P M} \pm \mathbf{S E}$ & $80.17^{\mathrm{a}} \pm 2.30$ & $174.28^{b} \pm 2.82$ & $191.52^{c} \pm 2.38$ & $367.79^{d} \pm 2.91$ & $487.03^{e} \pm 3.60$ & \\
\hline \multicolumn{7}{|c|}{ Feed intake (g) } \\
\hline$\overline{\mathrm{T}_{0}}$ & 92.60 & 226.55 & 303.30 & 588.00 & 823.53 & $406.80^{\mathrm{a}} \pm 21.68$ \\
\hline $\mathrm{T}_{1}$ & 92.78 & 227.53 & 291.51 & 587.72 & 831.56 & $406.22^{\mathrm{a}} \pm 21.90$ \\
\hline $\mathrm{T}_{2}$ & 93.50 & 226.47 & 276.51 & 607.64 & 830.73 & $406.97^{\mathrm{a}} \pm 22.22$ \\
\hline $\mathrm{T}_{3}$ & 94.24 & 226.48 & 273.28 & 620.62 & 831.94 & $409.31^{b} \pm 22.42$ \\
\hline $\mathrm{T}_{4}$ & 92.22 & 226.62 & 275.75 & 623.45 & 831.62 & $409.93^{b} \pm 22.47$ \\
\hline $\mathrm{T}_{5}$ & 92.24 & 245.61 & 279.22 & 629.80 & 837.35 & $416.84^{c} \pm 22.46$ \\
\hline $\mathbf{P M} \pm \mathbf{S E}$ & $92.93^{\mathrm{a}} \pm 0.08$ & $229.88^{b} \pm 0.54$ & $283.26^{\mathrm{c}} \pm 1.56$ & $609.54^{\mathrm{d}} \pm 1.30$ & $831.12^{\mathrm{e}} \pm 0.38$ & \\
\hline \multicolumn{7}{|c|}{ Feed conversion ratio (FCR) } \\
\hline$\overline{\mathrm{T}_{0}}$ & 1.27 & 1.45 & 1.56 & 1.66 & 1.73 & $1.53 \pm 0.02$ \\
\hline $\mathrm{T}_{1}$ & 1.20 & 1.38 & 1.50 & 1.67 & 1.72 & $1.49 \pm 0.02$ \\
\hline $\mathrm{T}_{2}$ & 1.21 & 1.38 & 1.49 & 1.68 & 1.72 & $1.49 \pm 0.02$ \\
\hline $\mathrm{T}_{3}$ & 1.27 & 1.38 & 1.52 & 1.68 & 1.75 & $1.52 \pm 0.03$ \\
\hline $\mathrm{T}_{4}$ & 1.26 & 1.36 & 1.51 & 1.66 & 1.73 & $1.50 \pm 0.02$ \\
\hline $\mathrm{T}_{5}$ & 1.51 & 1.32 & 1.51 & 1.69 & 1.70 & $1.55 \pm 0.02$ \\
\hline $\mathbf{P M} \pm \mathbf{S E}$ & $1.29^{\mathrm{a}} \pm 0.03$ & $1.38^{\mathrm{b}} \pm 0.02$ & $1.51^{\mathrm{c}} \pm 0.02$ & $1.67^{\mathrm{d}} \pm 0.01$ & $1.72^{\mathrm{d}} \pm 0.01$ & \\
\hline
\end{tabular}

abc\&abcde Means with different superscript within row and column differ significantly $(\mathrm{P}<0.05)$, respectively; GM \pm PSE: Group mean \pm Pooled Standard error; $\mathrm{PM} \pm \mathrm{SE}$ : Period mean \pm Standard error. 
of groups. The DAM incorporation up to 5.5 percent level did not exert any adverse or beneficial effects on mean weight gains of broiler chickens in the present study. This clearly indicated that DAM up to 5.5 percent level in broiler diets safely replaced with costlier conventional feed ingredients such as maize and soybean. However, mean feed intakes between groups, periods and the interaction between group and period were found to be statistically significant $(\mathrm{P}<0.05)$. Significantly higher $(\mathrm{P}<0.05)$ mean feed intake was recorded in $\mathrm{T}_{5}$ followed by $\mathrm{T}_{4}$ and $\mathrm{T}_{3}$ and lower feed intake was recorded in $\mathrm{T}_{0}, \mathrm{~T}_{1}$ and $\mathrm{T}_{2}$.

Present results are corroborated with the findings of Parthasarthy et al. (2002) and Shukla et al. (2018) who also reported a non significant difference in weight gain in broiler chickens fed azolla at 0 and 5\% level in the diets. However, Alalade and Iyayi (2006) in their study did not observe any significant difference in weight gain of chicks fed with azolla meal even up to more than $5 \%$ level i.e. (at $0,5,10$ and $15 \%$ level) in the diet. Whereas, Shamna et al. (2013) reported reduced weight gain in Japanese quails fed sun dried azolla at more than 5\% level (i.e. at $7.5 \%$ and $10 \%$ levels).

Results of feed intake in present study are in agreement with the findings of Querubin et al. (1986) who also reported increased feed intake in broilers at 5\% level. However, studies of Balaji et al. (2009) and Dhumal et al. (2009) in broilers and Shamna et al. (2013) in quails reported increasing trends in feed intake with increasing level of azolla in the diets but the differences were statistically non-significant. Whereas, present findings are dissimilar with results of Alalade and Iyayi (2006) who observed reduced feed intake with increasing level of azolla. The inconsistency in the trend of feed intake could be due to differences in the nutrient composition of the diets and azolla species used (Alalade et al., 2007).

The mean FCR among groups did not differ significantly $(\mathrm{P}>0.05)$. However, the mean FCR between groups was ranged from 1.49 to 1.55 . The results of the present study are contrary with the findings of earlier workers (Parthasarathy et al., 2002; Alalade and Iyayi, 2006; Dhumal et al., 2009; and Saikia et al., 2014) who reported improved FCR in broiler chicks with increased levels of azolla in diets. Moreover, Basak et al. (2002) reported better performance (weight gain, feed intake and FCR) in broiler at 5\% level as compared to 10 and $15 \%$ levels of sun dried azolla containing diets. The range of FCR in the present study was quite appreciable and acceptable for recommendation to the commercial broiler rearing farmers for profitable broiler production.

\section{CONCLUSION}

It can be concluded that the dietary incorporation of dried azolla meal (up to $5.5 \%$ of diet) is a good source of nutrients and alternative sustainable feed ingredient for broiler chickens without affecting performance (weight gain and FCR).

\section{ACKNOWLEDGEMENTS}

The first author wishes to thank the honourable ViceChancellor, SKUAST-Jammu and Worthy Dean, Faculty of Veterinary Sciences and Animal Husbandry, R.S. Pura, Jammu for providing necessary facilities for successful completion of this research work.

\section{REFERENCES}

Alalade, O.A. and Iyayi, E.A. 2006. Chemical Composition and the feeding value of Azolla (Azolla pinnata) Meal for EggType Chicks. Int. J. Poult. Sci., 5(2): 137-141.

Alalade, O.A., Eustace, A., Iyayi, E.A., Taiwo, O. and Alalade, 2007. The nutritive value of azolla (Azolla pinnata) meal in diets for growing pullets and subsequent effect on laying performance. J. Poult. Sci., 44: 273-277.

Ali, M.A. and Leeson, S. 1995. Nutritional value and aquatic weeds in the diet of poultry. World's Poult. Sci. J., 50: 239251 .

AOAC, 2000. Official methods of analysis ( $16^{\text {th }}$ ed.). Association of Official Analytical Chemists. Washington, DC.

AOAC, 2007. Official methods of analysis ( $18^{\text {th }}$ ed.). Arlington, VA, USA: Association of Official Analytical Chemists. ISBN 0-935584-54-4.

Balaji, K., Jalaludeen, A., Churchil, R.R., Peethambaran, P.A. and Senthil Kumar, S. 2009. Effect of dietary inclusion of Azolla (Azolla pinnata) on production performance of broiler chicken. Indian J. Poult. Sci., 44(2): 195-198.

Basak, B., Pramanik, A.H., Rahmnan, M.S., Taradar, S.U. and Roy, B.C. 2002. Azolla (Azolla pinnata) as a feed ingredient in broiler ration. Int. J. Poult. Sci., 1: 29-32.

Cherryl, D., Prasad, R. and Jayalaxmi, P. 2013. A study on economics of inclusion of Azolla pinnata in swine rations. Int. J. Agric. Sci. Vet. Med., 1(4): 51-56. 
Daing, M.I. 2015. Effect of Tanniferous tree leaves on nutrient utilization, health status and growth performance of broiler chickens. MVSc Thesis submitted to Sher-e-Kashmir University of Agricultural Sciences and Technology of Jammu.

Dhumal, M.V., Siddiqui, M.F., Siddiqui, M.B.A. and Avari, P.E. 2009. Performance of broilers fed on different levels of Azolla meal. Indian J. Poult. Sci., 44(1): 65-68.

Duncan, B.B. 1955. Multiple range and multiple ' $F$ ' test: Biomet., 11: 1-42.

ESJK, 2014. Economic survey J and K 2013-2014. Directorate of Economics \& Statistics, $J \& K$.

ICAR, 2013. Nutrient Requirement of Animals-Poultry (ICARNIANP), Indian Council of Agricultural Research, New Delhi.

Indira, D. and Ravi, A. 2014. Feeding value of Azolla (Azolla pinnata) in buffalo calves. Int. J. Food, Agric. Vet. Sci., 4(2): 23-27.

Indira, D., Sarjan, R.K., Suresh, J., Venugopal, N.K. and Ravi, A. 2009. Azolla (Azolla pinnata) as feed supplement in buffalo calves on growth performance. Indian J. Anim.Nutr., 26(4): 345-348

Kathirvelan, C., Banupriya, S. and Purushothaman, M.R. 2015. Azolla- An Alternate and Sustainable Feed for Livestock. Int. J. Sci. Environ. Technol., 4(4): 1153 - 1157.

Khan, M., Pathak, A.K. and Singh, S. 2019. Nutrient metabolism, blood Indices and Immunity in Haemonchus contortus infected goats fed condensed tannins enriched densified complete feed blocks. Anim. Nutr. Feed Technol., 19: 417430.

Khatun, A., Ali, M.A. and Dingle, J.G. 1999. Composition of the nutritive value for laying hens of diets containing azolla (Azolla pinnata) based on formulation using digestible protein and digestible amino acid versus total protein and total amino acid. Anim. Feed Sci. Technol., 81 (1-2): 43-56.

Lakshmanan, A., Kumar, K. and Latha, P. 2017. Azolla - A Low Cost and Effective Feed Supplement to Poultry Birds. Int. J. Curr. Microbiol. Appl. Sci., 6(8): 3622-3627.

Letermea, P., Londono, A.M., Munoj, J.E., Jeimmy, Suarez, Bedoya, C.A., Souffrant, W.B. and Andre, B. 2009. Nutritional value of aquatic ferns (Azolla filiculoides Lam. and Salvinia molesta Mitchell) in pigs. Anim. Feed Sci. Technol., 149: 135-148.

Makkar, H.P.S. 2000. Quantification of tannins in tree foliage. $A$ laboratory manual for the FAO/IAEA coordinated research project. Joint FAO/IAEA working document, IAEA, Viena. pp. 1-26.

Parthasarathy, R., Kadrivel, R. and Kathaperumal, V. 2001. Studies on economics of utilizing Azolla in boiler rations. Cheiron, 30: 24-26.
Parthasarathy, R., Kadrivel, R. and Kathaperumal, V. (2002). Azolla as a partial replacement for fish meal in boiler rations. Indian Vet. J., 79: 144-146.

Pathak, A.K., Dutta, Narayan., Pattanaik, A.K., Singh, A., Narang, A. and Sharma, K. 2015. Effect of condensed tannins supplementation from tanniferous tree leaves on methane production and efficiency of microbial biomass production in vitro. Anim. Nutr. Feed Technol., 15(1): 91-100.

Pathak, A.K., Sharma, R.K. and Rastogi, A. 2014. Azolla: Future Potential Feedstuffs for livestock. In: Livestock Health and Production with Emphasis on Hilly Areas. (Gupta, S.K. et al. Edn.) Published by Noton Press, Chennai-600-005, pp. 115-127.

Pathak, A.K., Tiwari, S.P., Sharma, R.K., Rastogi, A. and Khan, N. 2019. Functional Feed Potential of Condensed Tannins containing Tree Leaves to Improve Poultry Health and Production. In: Conceptual understanding and future strategies for welfare friendly poultry production in India (Tiwari, S.P. et al. Edn). Proc. XXXVI IPSACON- 2019, Durg, India, pp. 13-18.

Porter, L.J., Hrstich, L.N. and Chan, B.G. 1986. The conversion of procyanidins and prodelphinidins to cyanidin and delphinidin. Phytochem., 25: 223-230.

Querubin, J., AlCantara, P.F., Luis, E.S. and Princesa, A.O. 1986. Chemical composition and feeding value of Azolla in broiler ration. Philip. J. Vet. Anim. Sci., 12: 65.

Rana, D., Katoch, S., Bandu, G.M., Rani, D. and Sankhyan,V. 2017. Biological Evaluation of Azolla in Ration of Commercial Chicken Broiler. J. Anim. Res., 7(3): 601-607.

Roy, D.C., Pakhira, M.C. and Roy, M. 2016. Estimation of amino acids, minerals and other chemical compositions of Azolla.Adv. Life Sci., 5(7): 2692-2696.

Saikia, N., Sapcota, D. and Hazarika, R. 2014. Effect of feeding Azolla (Azolla pinnata) meal to broilers: A field study in Assam. Indian J. Poult. Sci., 49(1): 113-114.

Shamna, T.P., Peethambaran, P.A., Jalaludeen, A., Joseph, L. and Aslam, M.K.M. 2013. Broiler characteristics of Japanese quails (Coturnixcoturnix japonica) at different levels of diet substitution with Azolla pinnata. Anim. Sci. Reprod., 7(2): 75-80.

Shoukat, Ara., Adil, S., Banday, M.T. and Khan, M.A. 2015. Feeding potential of aquatic fern Azolla in broiler chicken ration. J. Poult. Sci. Technol., 3: 15-19.

Shukla, M., Bhattacharyya, A., Shukla, P.K., Roy, D., Yadav, B. and Sirohi, R. 2018. Effect of Azolla feeding on the growth, feed conversion ratio, blood biochemical attributes and immune competence traits of growing turkeys, Vet. World, 11(4): 459-463. 
Singh, S., Pathak, A.K., Khan, Muzaffar and Sharma, R.K. 2015. Multi- nutrient blocks with and without tanniferous leaf meal mixture: Formulation and preparation under sub-tropical environment of Jammu. J. Anim. Res., 5(1): 7-14

Sinha, Bidya Shankar, Kumar, Sanjeet and Chudhary, Govind Kumar. 2018. Use of Fresh Azolla as Dietary Supplementation in Backyard Poultry. Int. J. Curr. Microbiol. Appl. Sci., 7: 1358-1361.

Snedecor, G.W. and Cochran, W.E. 2004. Statistical Methods, $6^{\text {th }}$ Edn, Oxford and IBH Publishing Co., Delhi, India.

Talpatra, S.K., Ray, S.C. and Sen, K.C. 1940. Estimation of phosphorus, chlorine, calcium, magnesium, sodium and potassium in foodstuffs. Indian J. Vet. Sc. Anim. Husb., 10: 243-258.
Van Soest, P.J., Robertson, J.B. and Lewis, B.A. 1991. Methods for dietary fiber, neutral detergent fiber and non-starch polysaccharides in relation to animal nutrition. J. Dairy Sci., 74: 3583-3597.

Zargar, M.A., Pathak, A.K., Sharma, R.K. and Daing, M.I. 2020. Influence of Eugenia jambolana and Psidium guajava leaf meal mixture supplementation on carcass characteristics and economics of broiler chicks. J. Anim. Res., 10(3): 459-464. 
